\title{
Investigation and Thoughts on the Competency of New Young Teachers in Private Undergraduate Colleges*
}

\author{
Dan Chen \\ Department of Business Administration \\ Nanjing University of Finance and Economics Hongshan College \\ Nanjing, China
}

\begin{abstract}
The new young teachers are the main force of the teachers of our national undergraduate colleges. Their competency level has an important influence on the quality of talent training in private undergraduate colleges. Through the survey of 500 new young teachers in 20 private undergraduate colleges in 6 cities of Nanjing, Zhenjiang, Yangzhou, Suzhou, Xuzhou and Suqian in Jiangsu Province, it is found that the competence of new young teachers in private universities in Jiangsu Province is generally Basically achieved a good level, but the performance of young college teachers with different genders, different ages, different teaching ages, different professional titles and different academic qualifications is different. In order to effectively improve the competency of new young teachers in private colleges and universities, private colleges and universities should build a new promotion mechanism for young teachers' teaching competence, improve the training system for new young teachers' competence, and appropriately reduce the research pressure of young teachers in new universities to guide the independent growth of new young teachers.
\end{abstract}

Keywords-private undergraduate colleges; new young teachers; competence; investigation

\section{INTRODUCTION}

In recent years, with the rise of higher education popularization, the construction and development of private undergraduate colleges have sprung up. The large faculty of private colleges and universities relies on new young teachers. The competency of this group after entering the job is an important part of the soft power of private colleges. The recruitment, selection, training and assessment of this group is a new topic facing the human resources department of colleges and universities. Through the investigation and thinking of the new young teachers' competence in private undergraduate colleges, it provides guidance for the growth of new young teachers in private undergraduate colleges; it provides theoretical support for the recruitment, selection, training and performance appraisal of new teachers in

*Fund Project: This paper is the research result of the 2017 Jiangsu University Philosophy and Social Science Research Fund Project

"Construction and Application of New Youth Teacher Competency Model in Private Undergraduate Colleges” (Project No.: 2017SJB2117). private colleges and universities.

\section{RESEARCH TOOLS}

In this study, the scope of college teachers is defined in the colleges and universities who specialize in teaching and scientific research. The competence of college teachers is the ability of college teachers to be qualified for jobs and to achieve job performance. [1] This study uses the literature method, Delphi method, factor analysis method and statistical method to determine the competency of new young teachers in private undergraduate colleges as four dimensions of knowledge literacy, teaching ability, professional character and personality traits and educational knowledge, subject knowledge, general knowledge, instructional design, teaching implementation, teaching research and reform, professional attitude, professional emotion, career pursuit, self-characteristics and interpersonal characteristics, and design corresponding questionnaires. The content of the questionnaire consists of three parts: the first part is the basic information of the respondents, there are 11 items; the second part is the teacher's teaching competency assessment, which consists of a set of statements, there are 43 items, each statement is "very non-conformity, less consistent, slightly inconsistent, somewhat consistent, more consistent, fully in line with the" six answers, respectively 1 to 6 points; the third part of the teacher's teaching related situation survey, including 28 items. After the test and the reliability and validity test, the questionnaire can be used to evaluate the competency of new young teachers in private undergraduate colleges.

\section{THE RESEARCH OBJECT}

The research object of this paper is located in the relevant personnel of 6 private colleges in Jiangsu Province engaged in teaching and scientific research for 1-3 years. From October to December 2017, 500 questionnaires were distributed to 20 private undergraduate colleges in 6 cities including Nanjing, Zhenjiang, Yangzhou, Suzhou, Xuzhou and Suqian, and 479 were collected, with a recovery rate of $95.8 \%$. 463 copies, the effective rate was $92.6 \%$. From the perspective of gender, male teachers accounted for $46 \%$ of female teachers accounted for $54 \%$; from the academic level, 
doctors accounted for $18.79 \%$, masters accounted for $80.56 \%$, and bachelors accounted for $0.65 \%$; from the nature of teaching departments, liberal arts teachers accounted for $49.89 \%$, science teachers accounted for $26.57 \%$, engineering teachers accounted for $17.49 \%$, other teachers accounted for $6.05 \%$; from the category of teaching courses, professional teachers accounted for $51.45 \%$, public teachers accounted for $19.65 \%$, and both teachers accounted for $28.94 \%$; the above data show that this survey The gender, education, teaching, teaching courses, and geography of the subjects all have a certain proportion, which is in line with the current distribution of new young teachers in private colleges and universities in Jiangsu Province.

\section{THE RESEARCH RESULTS}

\section{A. The Overall Level of Competency of New Young Teachers in Private Undergraduate Colleges}

TABLE I. SCORES OF VARIOUS INDICATORS FOR NEW JUNIOR TEACHERS IN PRIVATE UNDERGRADUATE COLLEGES

\begin{tabular}{|c|c|c|c|c|c|}
\hline Index & Score & Index & Score & Index & Score \\
\hline $\begin{array}{c}\text { Professional } \\
\text { ideal }\end{array}$ & 5.46 & $\begin{array}{l}\text { Enterprising } \\
\text { heart }\end{array}$ & 4.99 & $\begin{array}{l}\text { Classroom } \\
\text { organization }\end{array}$ & 4.81 \\
\hline Impartiality & 5.25 & $\begin{array}{l}\text { Communication } \\
\text { skills }\end{array}$ & 4.99 & $\begin{array}{l}\text { Teacher- } \\
\text { student } \\
\text { interaction }\end{array}$ & 4.81 \\
\hline $\begin{array}{c}\text { Information } \\
\text { acquisition } \\
\text { and } \\
\text { processing }\end{array}$ & 5.24 & $\begin{array}{l}\text { Teaching goal } \\
\text { setting }\end{array}$ & 4.97 & team spirit & 4.79 \\
\hline Responsibility & 5.18 & $\begin{array}{l}\text { Professional } \\
\text { belief }\end{array}$ & 4.97 & $\begin{array}{l}\text { Inspiration } \\
\text { skills }\end{array}$ & 4.79 \\
\hline $\begin{array}{l}\text { Critical } \\
\text { thinking }\end{array}$ & 5.16 & $\begin{array}{l}\text { Teaching } \\
\text { content } \\
\text { arrangement }\end{array}$ & 4.96 & $\begin{array}{l}\text { sense of } \\
\text { humor }\end{array}$ & 4.77 \\
\hline $\begin{array}{c}\text { Love } \\
\text { teaching }\end{array}$ & 5.11 & $\begin{array}{l}\text { language } \\
\text { expression }\end{array}$ & 4.95 & $\begin{array}{l}\text { Natural } \\
\text { science } \\
\text { knowledge }\end{array}$ & 4.76 \\
\hline $\begin{array}{l}\text { Teaching } \\
\text { reflection }\end{array}$ & 5.08 & $\begin{array}{l}\text { Teaching } \\
\text { Evaluation }\end{array}$ & 4.95 & $\begin{array}{l}\text { Educational } \\
\text { theory }\end{array}$ & 4.72 \\
\hline $\begin{array}{l}\text { Professional } \\
\text { identity }\end{array}$ & 5.04 & $\begin{array}{l}\text { Educational } \\
\text { practical } \\
\text { knowledge }\end{array}$ & 4.9 & $\begin{array}{l}\text { Self } \\
\text { confidence }\end{array}$ & 4.71 \\
\hline $\begin{array}{l}\text { Teaching } \\
\text { Reform }\end{array}$ & 5.04 & Tolerance & 4.9 & $\begin{array}{l}\text { Teaching } \\
\text { object } \\
\text { analysis }\end{array}$ & 4.68 \\
\hline Rigor & 5.03 & $\begin{array}{l}\text { Teaching } \\
\text { method } \\
\text { selection } \\
\end{array}$ & 4.89 & $\begin{array}{l}\text { Self- } \\
\text { regulation }\end{array}$ & 4.67 \\
\hline $\begin{array}{c}\text { Subject } \\
\text { knowledge }\end{array}$ & 5.01 & $\begin{array}{l}\text { Teaching } \\
\text { demonstration }\end{array}$ & 4.89 & $\begin{array}{l}\text { Professional } \\
\text { realm }\end{array}$ & 4.65 \\
\hline $\begin{array}{l}\text { Motivating } \\
\text { art }\end{array}$ & 5.03 & $\begin{array}{l}\text { Use } \\
\text { educational } \\
\text { technology }\end{array}$ & 4.86 & $\begin{array}{l}\text { Humanities } \\
\text { and social } \\
\text { science } \\
\text { knowledge }\end{array}$ & 4.59 \\
\hline $\begin{array}{l}\text { Caring for } \\
\text { students }\end{array}$ & 5.00 & Adaptability & 4.85 & $\begin{array}{l}\text { Teaching } \\
\text { research }\end{array}$ & 4.23 \\
\hline Persistence & 5.00 & $\begin{array}{l}\text { Frontier } \\
\text { knowledge }\end{array}$ & 4.8 & & \\
\hline
\end{tabular}

From the results of the evaluation, the scores of knowledge literacy of the young teachers in private colleges and universities were 4.79 , the teaching ability was 4.94 , the professional character was 5.04, the personality trait was 4.90, and the comprehensive performance was 4.92. If 6 points are converted to excellent, 5 points conversion is good 4 points are converted to qualified, and the rest of the performance is converted into unqualified, we can draw a conclusion that the overall performance of the teaching competence of the young teachers in private colleges and universities is basically in good level or close to good level, but it shows certain specific indicators. The indicators to achieve a good level are: professional ideal, incentive art, justice, information acquisition and processing, responsibility, critical thinking, love of teaching, teaching reflection, professional identity, teaching reform, rigor, basic knowledge of the subject, caring for students and perseverance and so on. There is a certain gap between other indicators and good water. "Table I"

\section{B. Comparison of Teaching Competency of Young Teachers in Universities}

In order to further understand the current status of the competency of new young teachers in private colleges and universities, that is, whether there are differences in the competence of new young teachers with different characteristics in private colleges and universities, this study mainly adopts independent sample t test and single factor analysis of variance analysis into the data processing.

1) Gender differences: The independent sample t test was used to examine the gender of young teachers in Colleges and universities. "Table II"

TABLE II. INDEPENDENT SAMPLE T TEST RESUlTS OF NEW YOUNG TEACHERS' GENDER

\begin{tabular}{|c|c|c|c|c|c|c|}
\hline $\begin{array}{l}\text { Measurement } \\
\text { standard }\end{array}$ & Gender & $\mathbf{n}$ & $\mathbf{M}$ & SD & $\mathbf{t}$ & $\mathbf{P}$ \\
\hline \multirow{2}{*}{ Knowledge literacy } & male & 213 & 29.64 & 3.28 & \multirow{2}{*}{0.243} & \multirow{2}{*}{0.701} \\
\hline & Female & 250 & 29.73 & 3.163 & & \\
\hline \multirow{2}{*}{ teaching ability } & male & 213 & 69.91 & 8.57 & \multirow{2}{*}{18.976} & \multirow{2}{*}{0.000} \\
\hline & Female & 250 & 71.49 & 6.459 & & \\
\hline \multirow{2}{*}{$\begin{array}{c}\text { Professional } \\
\text { character }\end{array}$} & male & 213 & 44.26 & 5.524 & \multirow{2}{*}{10.909} & \multirow{2}{*}{0.001} \\
\hline & Female & 250 & 45.19 & 4.939 & & \\
\hline \multirow{2}{*}{ Personality Traits } & male & 213 & 44.49 & 4.312 & \multirow{2}{*}{3.419} & \multirow{2}{*}{0.072} \\
\hline & Female & 250 & 44.58 & 3.993 & & \\
\hline
\end{tabular}

The results of independent sample t-test showed that the difference between the male teacher and the female teacher was extremely significant in the teaching ability and professional character $(\mathrm{P}<0.01)$. There was no significant difference in the scores between the two sides in terms of knowledge literacy and personality traits. The descriptive data shows that the average number of female teachers is higher than that of male teachers in terms of teaching ability and professional character, while the two sides are basically equal in terms of knowledge literacy and personality traits.

2) Educational differences: A one-way analysis of variance was conducted for the level of college teachers' academic qualifications. "Table III" 
TABLE III. ONE-WAY ANALYSIS OF VARIANCE OF NEW JUNIOR TEACHERS' ACADEMIC LEVEL

\begin{tabular}{|c|c|c|c|c|c|c|}
\hline $\begin{array}{c}\text { Measurement } \\
\text { standard }\end{array}$ & $\begin{array}{c}\text { Education } \\
\text { level }\end{array}$ & $\mathbf{n}$ & M & SD & $\mathbf{F}$ & $\mathbf{P}$ \\
\hline \multirow{3}{*}{$\begin{array}{c}\text { Knowledge } \\
\text { literacy }\end{array}$} & Bachelor & 3 & 30.2 & 3.42 & \multirow{3}{*}{1.396} & \multirow{3}{*}{0.224} \\
\hline & $\begin{array}{l}\text { master's } \\
\text { degree }\end{array}$ & 373 & 29.53 & 3.252 & & \\
\hline & Doctor & 87 & 29.48 & 3.04 & & \\
\hline \multirow{3}{*}{ Teaching ability } & Bachelor & 3 & 71.47 & 7.122 & \multirow{3}{*}{1.823} & \multirow{3}{*}{0.12} \\
\hline & $\begin{array}{l}\text { master's } \\
\text { degree }\end{array}$ & 373 & 70.65 & 7.38 & & \\
\hline & Doctor & 87 & 70.09 & 7.781 & & \\
\hline \multirow{3}{*}{$\begin{array}{c}\text { Professional } \\
\text { character }\end{array}$} & Bachelor & 3 & 45.83 & 4.69 & \multirow{3}{*}{2.26} & \multirow{3}{*}{0.029} \\
\hline & $\begin{array}{l}\text { master's } \\
\text { degree }\end{array}$ & 373 & 44.75 & 5.322 & & \\
\hline & Doctor & 87 & 44.69 & 5.167 & & \\
\hline \multirow{3}{*}{$\begin{array}{c}\text { Personality } \\
\text { Traits }\end{array}$} & Bachelor & 3 & 44.89 & 3.918 & \multirow{3}{*}{1.472} & \multirow{3}{*}{0.214} \\
\hline & $\begin{array}{l}\text { master's } \\
\text { degree }\end{array}$ & 373 & 44.37 & 4.109 & & \\
\hline & Doctor & 87 & 44.25 & 4.19 & & \\
\hline
\end{tabular}

The results of one-way analysis of variance showed that the differences in teachers with different academic qualifications were significant $(\mathrm{P}<0.05)$. After the experience, multiple comparisons, in terms of knowledge literacy, teaching ability, professional character and personality traits, the average number of teachers with bachelor's degree and master's degree was significantly different $(\mathrm{P}<0.05)$. The descriptive data shows that in terms of knowledge literacy and professional character, the average number of young teachers with bachelor degrees is higher than that of masters and doctoral degree holders; in terms of teaching ability and personality traits, the average number of teachers with bachelor degrees is higher than that of masters and doctors. .

3) Professional birth differences: An independent sample $t$ test is conducted for whether the majors of young colleges and universities are professional for the teacher profession. "Table IV"

TABLE IV. INDEPENDENT SAMPLE T TEST OF PROFESSIONALLY-BORN YOUNG TEACHERS

\begin{tabular}{|c|c|c|c|c|c|c|}
\hline $\begin{array}{l}\text { Measurement } \\
\text { standard }\end{array}$ & $\begin{array}{c}\text { Whether it } \\
\text { is a teacher } \\
\text { class }\end{array}$ & $\mathbf{n}$ & $\mathbf{M}$ & SD & $\mathbf{t}$ & $\mathbf{P}$ \\
\hline \multirow{2}{*}{$\begin{array}{c}\text { Knowledge } \\
\text { literacy }\end{array}$} & Yes & 111 & 29.71 & 3.211 & \multirow{2}{*}{0.875} & \multirow{2}{*}{0.312} \\
\hline & No & 352 & 29.77 & 3.223 & & \\
\hline \multirow{2}{*}{ Teaching ability } & Yes & 111 & 70.95 & 7.372 & \multirow{2}{*}{0.138} & \multirow{2}{*}{0.211} \\
\hline & No & 352 & 70.73 & 7.638 & & \\
\hline \multirow{2}{*}{$\begin{array}{c}\text { Professional } \\
\text { character }\end{array}$} & Yes & 111 & 44.84 & 5.117 & \multirow{2}{*}{0.311} & \multirow{2}{*}{0.068} \\
\hline & No & 352 & 44.72 & 5.274 & & \\
\hline \multirow{2}{*}{$\begin{array}{c}\text { Personality } \\
\text { Traits }\end{array}$} & Yes & 111 & 44.45 & 4.089 & \multirow{2}{*}{0.764} & \multirow{2}{*}{0.272} \\
\hline & No & 352 & 44.52 & 4.052 & & \\
\hline
\end{tabular}

The independent sample $t$ test results showed that there was no significant difference in knowledge literacy, teaching ability, professional character, and personality traits $(\mathrm{P}>0.05)$. The descriptive data shows that in terms of knowledge literacy, teaching ability, professional character and personality traits, the teacher-professional teachers and nonteacher-professional teachers are basically the same.
4) Differences in the teaching category: A one-way analysis of variance was conducted for the young teachers in colleges and universities. "Table V"

TABLE V. ONE-WAY ANALYSIS OF VARIANCE OF NEW JUNIOR TEACHERS IN THE TEACHING CATEGORY

\begin{tabular}{|c|c|c|c|c|c|c|}
\hline $\begin{array}{c}\text { measurement } \\
\text { standard }\end{array}$ & $\begin{array}{c}\text { Course } \\
\text { category }\end{array}$ & $\mathbf{n}$ & M & SD & $\mathbf{F}$ & $\mathbf{P}$ \\
\hline \multirow{4}{*}{$\begin{array}{c}\text { Knowledge } \\
\text { literacy }\end{array}$} & liberal arts & 231 & 29.69 & 3.192 & \multirow{4}{*}{0.596} & \multirow{4}{*}{0.924} \\
\hline & science & 123 & 29.76 & 3.274 & & \\
\hline & Engineering & 81 & 29.74 & 3.172 & & \\
\hline & other & 28 & 30.14 & 3.388 & & \\
\hline \multirow{4}{*}{$\begin{array}{l}\text { teaching } \\
\text { ability }\end{array}$} & liberal arts & 231 & 71.07 & 7.454 & \multirow{4}{*}{1.832} & \multirow{4}{*}{0.122} \\
\hline & science & 123 & 70.6 & 7.636 & & \\
\hline & Engineering & 81 & 70.29 & 7.435 & & \\
\hline & other & 28 & 71.22 & 7.377 & & \\
\hline \multirow{4}{*}{$\begin{array}{l}\text { Professional } \\
\text { character }\end{array}$} & liberal arts & 231 & 45 & 5.15 & \multirow{4}{*}{2.265} & \multirow{4}{*}{0.09} \\
\hline & science & 123 & 44.76 & 5.233 & & \\
\hline & Engineering & 81 & 44.29 & 5.178 & & \\
\hline & other & 28 & 44.8 & 5.453 & & \\
\hline \multirow{4}{*}{$\begin{array}{c}\text { Personality } \\
\text { Traits }\end{array}$} & liberal arts & 231 & 44.54 & 4.153 & \multirow{4}{*}{0.472} & \multirow{4}{*}{0.814} \\
\hline & science & 123 & 44.39 & 4.038 & & \\
\hline & Engineering & 81 & 44.49 & 3.989 & & \\
\hline & other & 28 & 44.42 & 3.617 & & \\
\hline
\end{tabular}

The results of one-way analysis of variance showed that there was no significant difference in the mean between teachers in different subject categories in terms of knowledge literacy, teaching ability and personality traits $(\mathrm{P}>0.05)$. The descriptive data shows that in terms of teaching ability, professional character and personality traits, the average number of liberal arts teachers is higher than that of science and engineering teachers; in terms of knowledge literacy, the average difference of teachers in various disciplines is not significant.

5) Differences in teaching type: A one-way analysis of variance was conducted for the types of young teachers in colleges and universities. "Table VI" 
TABLE VI. ONE-WAY ANOVA ANALYSIS OF THE TYPES OF NEW YOUNG TEACHERS' TEACHING COURSES

\begin{tabular}{|c|c|c|c|c|c|c|}
\hline $\begin{array}{c}\text { Measurement } \\
\text { standard }\end{array}$ & $\begin{array}{c}\text { Teaching } \\
\text { course }\end{array}$ & $\mathbf{n}$ & M & SD & $\mathbf{F}$ & $\mathbf{P}$ \\
\hline \multirow{3}{*}{$\begin{array}{c}\text { Knowledge } \\
\text { literacy }\end{array}$} & $\begin{array}{l}\text { Public } \\
\text { Courses }\end{array}$ & 238 & 29.35 & 3.003 & \multirow{3}{*}{8.653} & \multirow{3}{*}{0.000} \\
\hline & $\begin{array}{l}\text { Professional } \\
\text { course }\end{array}$ & 91 & 29.98 & 3.319 & & \\
\hline & Both teach & 134 & 29.58 & 3.155 & & \\
\hline \multirow{3}{*}{$\begin{array}{l}\text { Teaching } \\
\text { ability }\end{array}$} & $\begin{array}{l}\text { Public } \\
\text { Courses }\end{array}$ & 238 & 69.96 & 7.404 & \multirow{3}{*}{4.823} & \multirow{3}{*}{0.012} \\
\hline & $\begin{array}{l}\text { Professional } \\
\text { course }\end{array}$ & 91 & 71.09 & 7.525 & & \\
\hline & Both teach & 134 & 70.85 & 7.494 & & \\
\hline \multirow{3}{*}{$\begin{array}{l}\text { Professional } \\
\text { character }\end{array}$} & $\begin{array}{l}\text { Public } \\
\text { Courses } \\
\end{array}$ & 238 & 44.26 & 4.927 & \multirow{3}{*}{3.261} & \multirow{3}{*}{0.039} \\
\hline & $\begin{array}{l}\text { Professional } \\
\text { course }\end{array}$ & 91 & 44.93 & 5.395 & & \\
\hline & Both teach & 134 & 44.89 & 5.024 & & \\
\hline \multirow{3}{*}{$\begin{array}{c}\text { Personality } \\
\text { Traits }\end{array}$} & $\begin{array}{l}\text { Public } \\
\text { Courses }\end{array}$ & 238 & 44.32 & 3.845 & \multirow{3}{*}{2.472} & \multirow{3}{*}{0.094} \\
\hline & $\begin{array}{l}\text { Professional } \\
\text { course }\end{array}$ & 91 & 44.65 & 4.171 & & \\
\hline & Both teach & 134 & 44.37 & 4.044 & & \\
\hline
\end{tabular}

The results of one-way analysis of variance showed that the mean difference between the teachers who taught different courses in terms of knowledge literacy, teaching ability and professional character was significant $(\mathrm{P}<0.05)$. After the experience, multiple comparisons, in terms of knowledge literacy, the difference between the public teacher and the teacher teaching the two teachers was significantly different $(\mathrm{P}<0.001)$. In terms of teaching ability, the professional teacher and the teacher who taught the two were respectively There was a significant difference between the averages of the teachers in the public classes $(\mathrm{P}<0.05)$, and the difference between the average number of teachers in the professional class and the teachers who taught the two was not significant. The descriptive data shows that in terms of knowledge literacy, teaching ability and professional character, the average difference between the professional teacher and the teacher who teaches both is small, and the average of both is higher than that of the public teacher; in terms of personality traits, the three The gap between the two is small.

\section{CONCLUSION}

\section{A. Basic conclusions}

- The competency of new young teachers in private undergraduate colleges has basically reached a good level but there are weak links. At present, the competency of new young teachers in private colleges has basically reached a good level, but some indicators are relatively weak. In the knowledge literacy dimension, educational theory knowledge, natural science knowledge, and humanities and social sciences are weak. There are certain gaps in the teaching ability dimension, teaching research, teaching object analysis, inspiration skills, teacherstudent interaction, classroom organization, etc.; in the professional character dimension, the professional realm score is low; in the personality trait dimension, self-regulation, self-confidence, humor Feelings and a spirit of cooperation are relatively lacking.

- The performance of new young teachers in different private colleges is different. In terms of teaching ability and professional character, the scores of male teachers and female teachers are significantly different, and female teachers are more prominent in these two aspects. The scores of teachers with different academic qualifications are significantly different, and the scores of undergraduate teachers are the highest; the scores of teachers from different majors, different colleges, different subjects and courses are not significant.

- Young teachers in private undergraduate colleges pay insufficient attention to teaching research. Judging from the scores of competency indicators, young college teachers are not active enough in teaching research. According to the survey results, more than half of the young teachers who did not undertake the teaching and research topics, and $67.1 \%$ of the young teachers did not publish the results of teaching and research. In terms of scientific research, $51 \%$ of young college teachers did not participate in research projects, while the proportion of young teachers who hosted research projects at the provincial level or above reached $30.4 \%$, and young people who published scientific research achievements reached 3 (be) and above. Teachers accounted for $55.3 \%$. From the perspective of undertaking the subject and publishing the results, the young teachers in colleges and universities clearly showed a tendency to focus on scientific research and light research.

\section{B. Suggestions}

1) Constructing the promotion mechanism of new junior teachers' competence in private undergraduate colleges: The promotion mechanism for constructing the new junior teachers' competence in private colleges and universities can be started from the following aspects. The first is to set up a new youth teacher teaching competency promotion center. The mission of the center is to discuss modern educational theory and practice, provide teaching advice and training teaching skills for new young teachers. The second is to improve the evaluation mechanism for new young teachers' teaching posts. Including the new professional teachers' title evaluation and appointment teaching evaluation system, and the unqualified teachers to transfer the teaching post system, so as to promote the new teachers to continuously improve the teaching level. The third is to form an effective teaching reward mechanism. Form a policy orientation that emphasizes both teaching and research, in order to encourage new young teachers to think, research and improve teaching. The fourth is to establish a competency assessment and monitoring mechanism. Colleges and universities should develop a new and reasonable teacher competency evaluation system that is scientific and reasonable and easy to operate, in order to 
objectively reflect the teaching competency of college teachers.

2) Improving the training system for the teaching competence of young teachers in private colleges and universities: For young teachers, colleges and universities should establish and improve the pre-service training system for teachers, the lecture and teaching assistant system before the lectures, the trial system for new courses, the tutor system for paired help, the training system for modern educational technology, and the study of teaching and learning system and so on. At the same time, it is necessary to carry out various forms of teaching and practice activities for young teachers, such as various teaching competitions and various teaching theme activities. The former includes teacher lectures, multimedia courseware competitions, classroom teaching design, excellent teaching plan competitions, etc.; the latter includes demonstrations of outstanding young teachers. Class observation, teaching lectures, regular meetings of teaching and research rooms, teaching counseling reports and exchange of teaching experience.

3) Appropriately reducing the scientific research pressure of new young teachers in private undergraduate colleges: At present, private colleges and universities have high scientific research requirements for new teachers, and the pressure on new young teachers is too high. In this case, their priority is to get high-level scientific research topics and publish papers in high-level journals in order to get the promotion chip. This has forced many young college teachers to focus on scientific research and publishing scientific research. In view of this, colleges and universities should appropriately reduce the scientific research requirements of new young teachers, reduce their scientific research pressure, give them relatively abundant accumulation time, and provide a more relaxed environment for them to improve their competency. Guide the independent growth of new young teachers in private colleges and universities. Private undergraduate colleges should strive to create an environment of independent growth and encourage new young teachers to reflect and act autonomously. [2] The first is to improve knowledge literacy. New young teachers should constantly update their teaching knowledge and other relevant knowledge while constantly updating their professional knowledge, and continuously enhance their cultural heritage. The second is to cultivate professionalism. New young teachers must establish firm professional convictions and constantly pursue new and higher professional realms. The third is to strengthen teaching reflection. Teaching reflection is the basis for the improvement of teaching ability. Writing a teaching diary, observing teaching, participating in discussions, and conducting action research are the main ways to reflect on teaching. The fourth is to cultivate spiritual temperament. [3] The spiritual temperament of new teachers is composed of personal words and deeds, personality and internal cultivation, and young college teachers should be consciously cultivated and improved.

\section{REFERENCES}

[1] Huang Zhiming. Construction and application of new recruiting young teachers in colleges and universities [D]. Anhui University of Finance and Economics, 2015.11-15.

[2] Xiong Peng, He Qizong. Investigation and Thinking on the Teaching Competency of Young Teachers in Colleges and Universities [J] Educational Research, 2016(11).126-132.

[3] Boyatzis, Burros. Distinguish Contextual Performance from Task Performance for Managerial Jobs. [J].Journal of APP lied Psychology, 1999(84). 